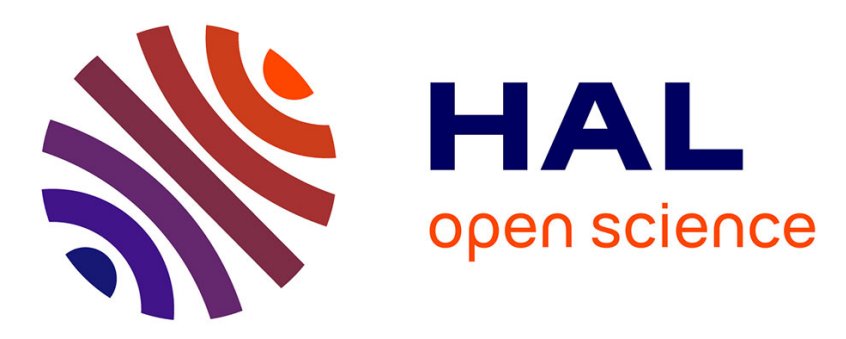

\title{
Exterior and under glass natural weathering of hemp fibers reinforced polypropylene biocomposites: Impact on mechanical, chemical, microstructural and visual aspect properties
}

Célia Badji, J. Beigbeder, Hélène Garay, Anne Bergeret, Jean-Charles Benezet, Valérie Desauziers

\section{To cite this version:}

Célia Badji, J. Beigbeder, Hélène Garay, Anne Bergeret, Jean-Charles Benezet, et al.. Exterior and under glass natural weathering of hemp fibers reinforced polypropylene biocomposites: Impact on mechanical, chemical, microstructural and visual aspect properties. Polymer Degradation and Stability, 2018, 148, pp.104-116. 10.1016/j.polymdegradstab.2017.12.015 . hal-02479344

\author{
HAL Id: hal-02479344 \\ https://hal.science/hal-02479344
}

Submitted on 1 Jun 2021

HAL is a multi-disciplinary open access archive for the deposit and dissemination of scientific research documents, whether they are published or not. The documents may come from teaching and research institutions in France or abroad, or from public or private research centers.
L'archive ouverte pluridisciplinaire HAL, est destinée au dépôt et à la diffusion de documents scientifiques de niveau recherche, publiés ou non, émanant des établissements d'enseignement et de recherche français ou étrangers, des laboratoires publics ou privés. 


\title{
Exterior and under glass natural weathering of hemp fibers reinforced polypropylene biocomposites: Impact on mechanical, chemical, microstructural and visual aspect properties
}

\author{
Célia Badji, Joana Beigbeder, Hélène Garay, Anne Bergeret*, Jean-Charles Bénézet, \\ Valérie Desauziers
}

C2MA, IMT Mines Ales, Université de Montpellier, 6 Avenue de Clavières, 30319 Alès Cedex, France

\begin{abstract}
A B S T R A C T
This work aims to investigate exterior and under glass weathering representing decking and car interior end uses of hemp fibers reinforced polypropylene (PP) biocomposites. For this reason, mechanical flexural tests were firstly performed. Then, the evolution of the PP matrix microstructure was determined through Differential Scanning Calorimetry (DSC). The chemical composition was studied by infrared spectroscopy to understand the photo- and thermo-chemical mechanisms. CIELab system-based colorimetric measurements were carried out to determine the evolution of the chromaticity and lightness. Through a new approach, gloss was obtained by determining the type of reflection of materials as either specular or diffuse, and the surface aspect was characterized by rugosimetry. The influence of the rate of hemp fibers (from 0 to $30 \mathrm{wt} \%$ ) was studied. Results showed that biocomposites were generally more sensitive than neat PP whatever the weathering conditions. However, each type of weathering assessment allowed understanding the contribution of each degradation factor. Indeed, rainfall or UV-A rays induced an increase in the vinyl concentration and the formation of cracks on the surface whereas the carbonyl functional groups rate was not influenced by the type of weathering. The high temperatures under windshield glass favored a chemicrystallization and biocomposites yellowing at the first period of exposition whereas outdoor exposure induced red color loss.
\end{abstract}

\author{
Keywords: \\ Hemp fibers \\ Degradation \\ Gloss \\ Roughness \\ Oxidation \\ Rain \\ Temperature
}

\section{Introduction}

Due to environment and sustainability issues, biocomposites have encountered remarkable interest in the last decades. They are developed in numerous industrial sectors such as construction (decking), automobile (door panels, dashboards) and sport (surfboard) replacing glass or carbon fibers reinforced composite materials [1]. Although they present lower mechanical performances than reinforced polymer composites glass fibers, their specific mechanical properties are excellent. Composites based on thermoplastics such as polypropylene (PP), polyethylene (PE), polyvinyl chloride (PVC) or polylactic acid (PLA) are widely used in modern society [2-4] at which the global production of PP is about 60 million MT per year and may reach 75 million MT in 2022 [5].

The high sensitivity of vegetal fibers to the climatic conditions for the reinforcement of biocomposites constitutes a drag for their use. Several recent studies in countries of different climates, such as Mediterranean [3], tropical [6,7], and continental [8,9], have been dealing with the natural exterior weathering of natural fibers reinforced composites to test their durability. The exposition induced their degradation and hypotheses were brought to explain the extrinsic variations. Indeed, radical-based oxidative processes due to high temperature or ultraviolet (UV) rays are responsible for the physico-chemical properties alteration. During the weathering, the polymer matrix degrades into lower molecular weight products by Norrish type I and II reactions chain scissions [9,10]. As a result, formation of quinoid structures, UV radiation absorption by lignin, Norrish reactions and photo-yellowing reactions occur and lead to the formation of chromophoric groups in the vegetal fibers. Also, the thermal degradation could particularly affect the hemicelluloses stability [11]. These chemical changes resulted in a mechanical performance loss, visual aspect and microstructural changes $[7,12,13]$. The degradation can be reduced by stabilizers incorporated during processing to slow down the photooxidation rate [14].

The influence of each exterior degradation factor was assessed by weathering carried out in laboratories allowing to uncouple these

\footnotetext{
* Corresponding author.

E-mail address: Anne.Bergeret@mines-ales.fr (A. Bergeret).
} 
parameters in order to understand their contribution on biocomposites properties evolution. Indeed, UV exposure of rice husks reinforced PLA biocomposites was studied in accordance with potential final applications [15]. It was compared to immersion and hygrothermal conditions. UV and hygrothermal aging carried out at $65^{\circ} \mathrm{C}$ and $85^{\circ} \mathrm{C}$, respectively presented a more significant effect on the polymer crystallinity rate than immersion. The increase in crystallinity rate was due to a chemicrystallization mechanism of PLA macromolecular chains favored at high temperature [16]. Otherwise, molecular weights and bending strength decreased more under hygrothermal aging conditions than under other weathering ones. Thwe and Liao [17] also investigated the hygrothermal aging of bamboo fibers reinforced PP composites. Samples were immersed in water at $25^{\circ} \mathrm{C}$ for 6 months and at $75{ }^{\circ} \mathrm{C}$ for 3 months. Tensile strength and modulus slightly decreased after aging for 6 months at $25^{\circ} \mathrm{C}$; however, they highly decreased after immersion at $75^{\circ} \mathrm{C}$. The interfacial adhesion was also affected due to debonding caused by the incompatibility between thermal and moisture expansion coefficients. The temperature promoted the water saturation phenomenon $[18,19]$. The immersion representing extreme water absorption conditions was also studied by Arbelaiz et al. [20]. The water uptake induced the swelling of fibers until reaching saturation that affected the interfacial adhesion and the mechanical properties. This also led to composite microcracks and dimensional instability. Bauer suggested that the rate of photo-oxidation due to UV rays exposition increased with temperature by an Arrenhius rate dependence [21]. The photooxidation rate of reinforced natural fibers composites also increased with humidity [11] since water facilitated the light penetration into the vegetal matter. Thus, a synergistic effect could also enlarge the degradation phenomenon during the weathering.

The effect of each component of the vegetal fibers (lignin, hemicellulose, non-cellulosic components for example) on the variations of biocomposites properties during the weathering has been investigated. Beg et al. evaluated the effects of the presence of lignin and hemicelluloses on composite properties. A better interfacial bonding and higher tensile strength were observed when bleached Kraft wood fibers are incorporated in PP all along the aging due to the removal of noncellulosic compounds [11]. Also, Peng et al. showed that the cellulose favored the formation of microcracks at the surface of reinforced cellulose fibers PP composites but no significant discoloration was observed [22]. Indeed, the high hygroscopicity of cellulose may induce composite swelling and thus a higher surface roughness than neat PP. The discoloration of composites was accelerated by the presence of lignin, especially at high content. It is widely accepted that a phenoxy quinone redox mechanism is implied in lignin decomposition [14]. In fact, the paraquinone structures with a characteristic yellow color formed after ageing are further decomposed into hydroquinone molecules which are responsible for the composites bleaching. However, it was recently demonstrated that the carbohydrate part of lignocellulosic materials could also undergo yellowing due to chromophoric carbonyl formation after photo-oxidation [23]. Moreover, Peng et al. noted that the presence of lignin induced a lower decrease in flexural strength and modulus of PP composites as well as a lower number of microcracks at the composite surface and a better surface hydrophobicity towards weathering than in presence of cellulose or wood flour [22]. The same improvement of mechanical properties in presence of lignin in reinforced cellulose fibers PP composites was noted by Gadioli et al. [24]. This anti-oxidant role of lignin can be explained by the presence of hindered phenols that prevent free radical-based reactions during the polymer stabilization process [22,24]. Otherwise, infrared spectroscopy revealed that an oxidative degradation of materials occurred whatever is the chosen lignocellulosic component for the composite reinforcement. Nevertheless, hemicelluloses reinforced thermoplastic composites were not studied because of their very low thermal stability that limited their process.

Several studies were investigated about natural and artificial weathering of exterior and interior pieces of cars made of paints and coatings [21,25-27]. The studies reported in the literature on the behavior of the interior pieces of the cars examine their Volatile Organic Compounds (VOCs) emissions and their impact on indoor air quality [28-30]. To our knowledge, any natural aging of natural reinforced fibers composites representing a car interior environment was reported in the literature.

The objective of this work is to assess the influence of the type of weathering, either exterior or under windshield glass, on the evolution of physico-chemical properties of reinforced hemp fibers PP biocomposites. Flexural properties as well as microstructural and chemical compositions were followed all over the weathering process. Visual and surface aspects were analyzed by optical measurements. A comparison between the two types of weathering was done for each material and each characterization to understand the effects of the parameters of weathering.

\section{Materials and methods}

\subsection{Materials}

Polypropylene grade H733-07 with a melt flow rate of $7.5 \mathrm{~g} / 10 \mathrm{~min}$ $\left(230^{\circ} \mathrm{C}, 2.16 \mathrm{~kg}\right)$ purchased from Braskem Co. (Brazil) was used as thermoplastic matrix. Hemp fibers $(2-6 \mathrm{~mm})$ were provided by AgroChanvre (France). After the retting process (38 days), their cellulose, hemicelluloses and lignin rates (Table 1) were determined by successive chemical extractions based on TAPPI T264, ASTM D1104 standards [31,32]. Two hemp fibers loading $10 \mathrm{wt} \%$ (PP10) and $30 \mathrm{wt} \%$ (PP30) were chosen (Table 2). Maleic anhydride grafted polypropylene (MA-g-PP) with a $1 \mathrm{wt} \%$ grafting rate (Orevac CA100) and supplied by Arkema (France), was added at $3.1 \mathrm{wt} \%$ of PP as coupling agent.

\subsection{Material processing}

Hemp fibers and MA-g-PP were dried before processing for $15 \mathrm{~h}$ at $60{ }^{\circ} \mathrm{C}$ in an oven to remove residual water. Granules of PP and MA-g-PP were mixed with hemp fibers in a BC21 Clextral co-rotating twin-screw extruder (L/D $=36$ with the diameter $\mathrm{D}=25 \mathrm{~mm}$ ) (Clextral, France) with the temperature profile $190-190-190-180-175-175-175^{\circ} \mathrm{C}$ from feed to die and a screw speed of $220 \mathrm{rpm}$. Once dried for 3 days at $60^{\circ} \mathrm{C}$, extruded pellets were molded in a Krauss Maffei KM50-T180CX (Krauss Maffei, Germany) at $210{ }^{\circ} \mathrm{C}$ with an injection speed of $30 \mathrm{~cm}^{3} \mathrm{~s}^{-1}$ to obtain square specimens of $100 \times 100 \times 2 \mathrm{~mm}$ and ISO 1 dog-bone specimens (Fig. 1).

\subsection{Weathering conditions}

Two types of natural weathering were carried out in the south west of France (Pau) between September 2015 and September 2016 allowing to include climatic conditions from the four annual seasons and to consider the contribution of each season to the degradation. The first exterior exposition corresponded to a decking use and the second one simulated a car interior environment. These two weathering conditions meet the ISO 877-1:2011 standard and ISO 877-2:2011 standard respectively $[33,34]$. The samples were fixed on galvanized racks at an angle of $45^{\circ}$ with the ground and directed towards the south. Laminated windshield glasses protected the materials for automotive application (Fig. 2). The designation of non-weathered and weathered materials is featured in Table 3. Dog-bone and square specimens were sampled after $1,2,3,6,9$ and 12 months for laboratory characterizations. Seasonal

Table 1

Hemp fibers chemical composition.

\begin{tabular}{lllllc}
\hline & Cellulose & Hemicelluloses & Lignin & Lipophilic extractives & Ash \\
\hline (wt $\%)$ & 82.1 & 8.5 & 4.5 & 2.7 & 2.1 \\
\hline
\end{tabular}


Table 2

Designation of materials.

\begin{tabular}{llll}
\hline & \multicolumn{2}{l}{ Composition $(w t \%)$} & \\
\cline { 2 - 4 } & PP & Hemp fibers & MA-g-PP \\
\hline PP & 100 & - & - \\
PP10 & 87.3 & 10 & 2.7 \\
PP30 & 67.9 & 30 & 2.1 \\
\hline
\end{tabular}

data such as solar radiation and pluviometry were recorded from PauUzein station [35] whereas laboratory sensors were used for monitoring temperature and relative humidity (Figs. 3 and 4). All along the aging, mean temperature was slightly higher under glass than outside with the biggest difference in August 2015. Otherwise, the min-max amplitude temperature values were greater under windshield glass. On the contrary, relative humidity was obviously lower under glass due to higher temperatures drying the indoor air. Thus, under glass weathering simulates a hot and dry climate whereas exterior aging represents moderate and humid climate.

\subsection{Mechanical characterization}

Before mechanical test, samples were conditioned for 3 days at $23 \pm 2{ }^{\circ} \mathrm{C}$ and $50 \pm 10 \% \mathrm{RH}$. Then, flexural properties characterization was performed by three point bending test carried out in the same hygrothermal conditions on ISO 1A dog-bone samples in accordance to the ISO 178:2010 standard [36]. A Zwick TH 010 press apparatus (Zwick, Germany) was used with a $2.5 \mathrm{kN}$ load cell. Elastic modulus $\mathrm{E}_{\mathrm{f}}$ calculated between 0.05 and $0.25 \%$ of strain and the stress at the conventional deflection $\sigma_{\mathrm{fc}}$ corresponding to the stress at a strain of $3.5 \%$ were deduced from stress-strain curves. The cross-head speeds were set at 2 and $100 \mathrm{~mm} \mathrm{~min}^{-1}$ for the modulus and flexural stress at the conventional deflection measurements, respectively. Eight samples of each material were tested to evaluate the reproducibility.

\subsection{Visual aspect characterization}

\subsubsection{Spectrocolorimetry}

The surface color analysis was performed with a Chroma Sensor 3 spectrocolorimeter (Datacolor, United States). The configuration illuminant/observer chosen was D65/10 . The CIE $1976 L^{*}, a^{*}, b^{*}$ uniform system was used. $L^{*}, a^{*}$ and $b^{*}$ were deduced from the reflectance curves. The $L^{*}$ coordinate represents the lightness whereas $a^{*}$ and $b^{*}$ represent the chromaticity. An increase of $\mathrm{L}^{*}$, from 0 to 100 , witnesses a material lightening. $a^{*}$ and $b^{*}$ are the chromaticity positions on axes from -300 to +300 which are green $\left(-a^{*}\right)$ to red $\left(+a^{*}\right)$ and blue $\left(-b^{*}\right)$ to yellow $\left(+b^{*}\right)$ axes, respectively. Values were obtained from the analysis of four areas of three samples.

\subsubsection{Spectrophotogoniometry}

The distribution of the intensity of light reflected by a material versus the angle of detection can be related to the surface aspect of a material [37]. Indeed, the gloss of a material is more pronounced as the light reflected directionally. On the contrary, a rough surface induces a diffuse reflection since the reflected light is not concentrated in a narrow bundle (Fig. 5). A GON 360 goniometer (Instrument Systems $\mathrm{GmbH}$, Germany) coupled to a MAS 40 spectrometer with a halogen lamp and a power supply of $12 \mathrm{~V}$ was used to collect the radiometric power. The source angle was fixed at $20^{\circ}$ according to ISO 2813 standard [38]. Detector angles varied from $5^{\circ}$ to $-60^{\circ}$ with an angular step smaller in the specular zone in order to detect the high variations of intensity in this zone. The spectral range of analysis was $380-780 \mathrm{~nm}$; moreover, from every spectrum $I=f(\lambda(n m))$ obtained for every detector angle, the total intensity can be represented versus the detector angle: $I($ u.a. $)=f\left(\Theta\left(^{\circ}\right)\right)$.

$\mathrm{G}_{1}$, corresponding to haze gloss, was determined from the ratio of the maximum intensity obtained for the angle of detection of $-20^{\circ} \mathrm{I}$ $\left(\Theta=-20^{\circ}\right)$ to the intensity obtained for the angle of $-22^{\circ} \mathrm{I}$ $\left(\Theta=-20+-2^{\circ}\right)$ at which both are situated in the specular zone (Eq. (1)). Moreover, the contrast gloss $\mathrm{G}_{2}$ which is the ratio of $\mathrm{I}\left(\Theta=-20^{\circ}\right)$ to the collected intensity of the angle at $-35^{\circ} \mathrm{I}\left(\Theta=-20+-15^{\circ}\right)$ of a diffusely reflected light far away from the specular zone was also calculated (Eq. (2)). The higher the values of $\mathrm{G}_{1}$ and $\mathrm{G}_{2}$, the glossier and smoother the surface looks. The gloss was computed for three replicates at four locations on each material.

$G 1=\frac{I\left(\Theta=-20^{\circ}\right)}{I\left(\Theta=-22^{\circ}\right)}$

$G 2=\frac{I\left(\Theta=-20^{\circ}\right)}{I\left(\Theta=-35^{\circ}\right)}$

\subsection{Microstructure characterization}

\subsubsection{Differential scanning calorimetry (DSC)}

A PYRIS Diamond calorimeter (Perkin Elmer, United States) was employed for the determination of the polymer crystallinity behavior during weathering. The measurements were carried out under nitrogen atmosphere at a flow rate of $20 \mathrm{~mL} \mathrm{~min}^{-1}$. The temperature ranged from 30 to $210^{\circ} \mathrm{C}$ with heating ramp of $10^{\circ} \mathrm{C} \cdot \mathrm{min}^{-1}$. Two heating steps, with an intermediate cooling step at $-10^{\circ} \mathrm{C} \cdot \mathrm{min}^{-1}$, were performed. Fragments of almost $10 \mathrm{mg}$ sampled at the surface of materials were placed into standard aluminium pans. Two replicate samples per material were analyzed. The crystallinity ratio was calculated according to the following equation taking into account the melting enthalpy:

$\chi c(\%)=\frac{\Delta H m}{W \times \Delta H m 100} \times 100$

where $\mathrm{W}$ is the PP mass fraction, $\Delta \mathrm{Hm}\left(\mathrm{J}^{-\mathrm{g}^{-1}}\right)$ is the melting enthalpy determined from the 1 st and 2 nd heating steps and $\Delta \mathrm{Hm}_{100}$ corresponds to the estimated melting enthalpy of a fully crystalline PP $\left(209 \mathrm{~J} \mathrm{~g}^{-1}\right)$ $[39,40]$.

\subsection{Chemical composition characterization}

\subsubsection{Fourier Transform InfraRed spectroscopy (FTIR)}

A IFS66 spectrometer (Bruker, United States) operating in the Attenuated Total Reflectance (ATR) mode was used to follow the
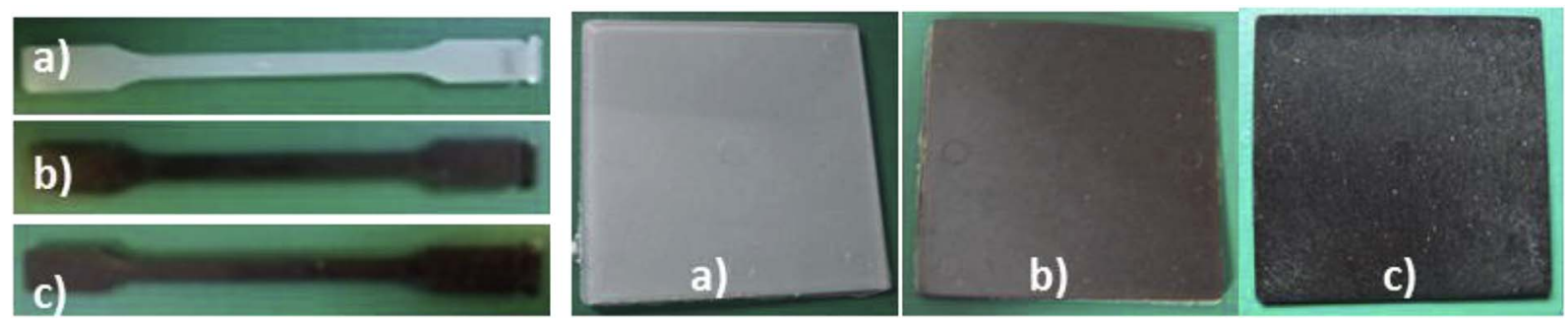

Fig. 1. PP (a), PP10 (b) and PP30 (c) materials: dog-bone specimens (left) and square specimens (right). 

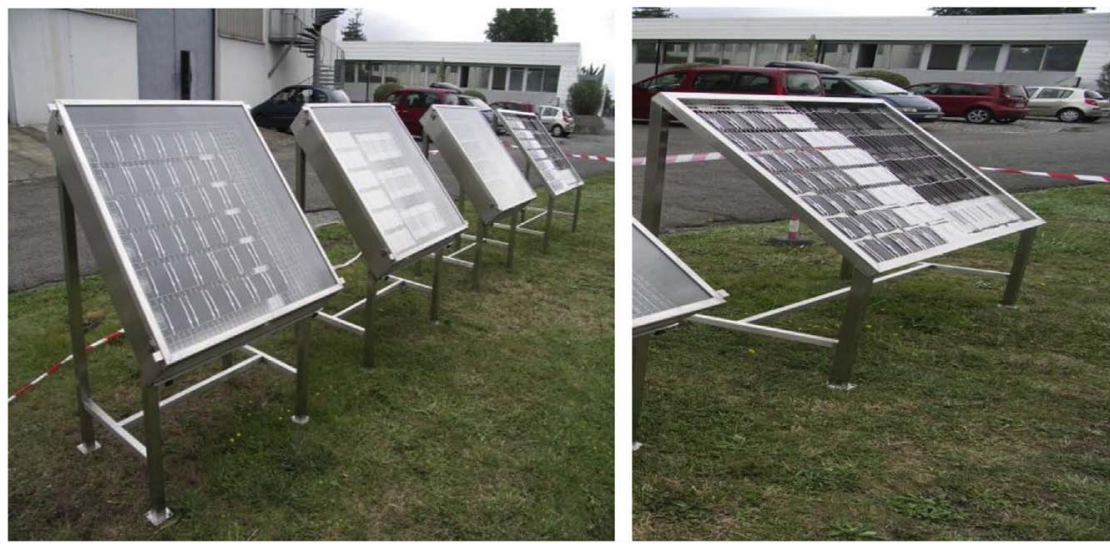

Table 3

Designation of PP, PP10, and PP30 unweathered and weathered materials.

\begin{tabular}{llll}
\hline & $\begin{array}{l}\text { Unweathered (UW) } \\
\text { materials }\end{array}$ & $\begin{array}{l}\text { Exterior weathered } \\
(\mathrm{EW}) \text { materials }\end{array}$ & $\begin{array}{l}\text { Under glass } \\
\text { weathered (GW) } \\
\text { materials }\end{array}$ \\
\hline Designation & $\begin{array}{l}\text { PP-UW, PP10-UW, } \\
\text { PP30-UW }\end{array}$ & $\begin{array}{l}\text { PP-EW, PP10-EW, } \\
\text { PP30-EW }\end{array}$ & $\begin{array}{l}\text { PP-GW, PP10-GW, } \\
\text { PP30-GW }\end{array}$ \\
\hline
\end{tabular}

functional groups specific to the polymer and biocomposites degradation. The device was equipped with a single reflection diamond crystal accessory. Thin slices of exposed surfaces were analyzed, and the spectra were recorded as the average of 32 scans in the 400 to $4000 \mathrm{~cm}^{-1}$ spectral range with a resolution of $1 \mathrm{~cm}^{-1}$. These infrared spectra were normalized according to the Min-Max normalization method with the $2925 \mathrm{~cm}^{-1}$ reference band assigned to the $\mathrm{CH}_{2}$ methylene groups.

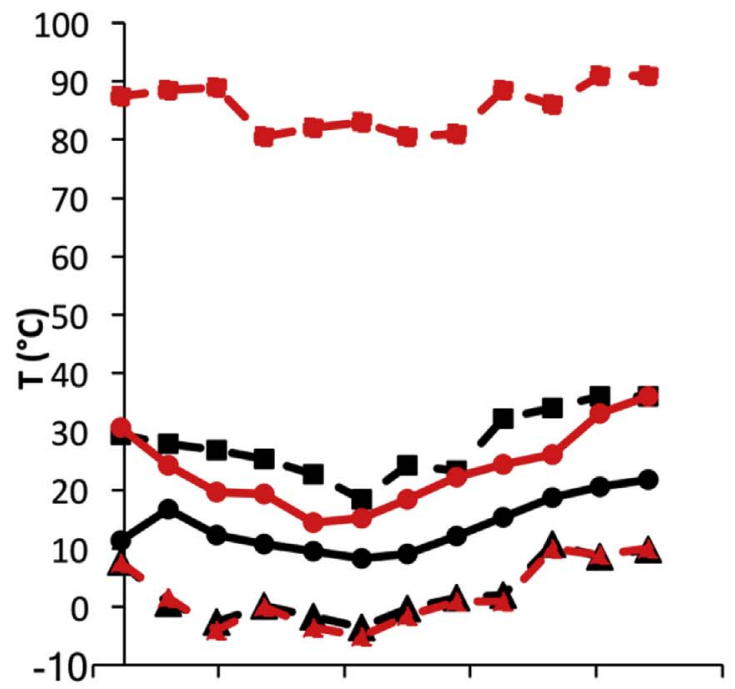

Aug-15 Nov-15 Jan-16 Apr-16 Jun-16 Sep-16

\subsection{Surface characterization}

\subsubsection{Confocal rugosimetric measurement}

A MICROMESURE STIL system equipped with a STIL CHR150 optical sensor (Aix en Provence, France) was used to evaluate the roughness by altitude measurement of each surface point on the sample without contact with the sample according to the ISO 25178 international standard. More details are given in a previous paper [12]. A bidimensional scanning allows obtaining the image of the sample surface located at a precise distance from the STIL optical sensor. Moreover, the acquisition software SurfaceMap allowed the control of the station and the post-treatment MountainsMap software was used to analyze the surface geometry and to calculate roughness parameters. The micrometric range of the optical pen was $285 \mu \mathrm{m}$. It permitted a tridimensional analysis at which the analyzed area was $5 \mathrm{~mm} * 5 \mathrm{~mm}$ with an analysis step of $10 \mu \mathrm{m}$ in both the $\mathrm{X}$ and $\mathrm{Y}$ directions. The tridimensional roughness parameter Sa followed during weathering corresponds to the arithmetic mean of the absolute of the height values (Eq. (4)):

$\mathrm{Sa}=\frac{1}{N M} \sum_{x=0}^{N-1} \sum_{y=0}^{M-1}|z(x, y)|$

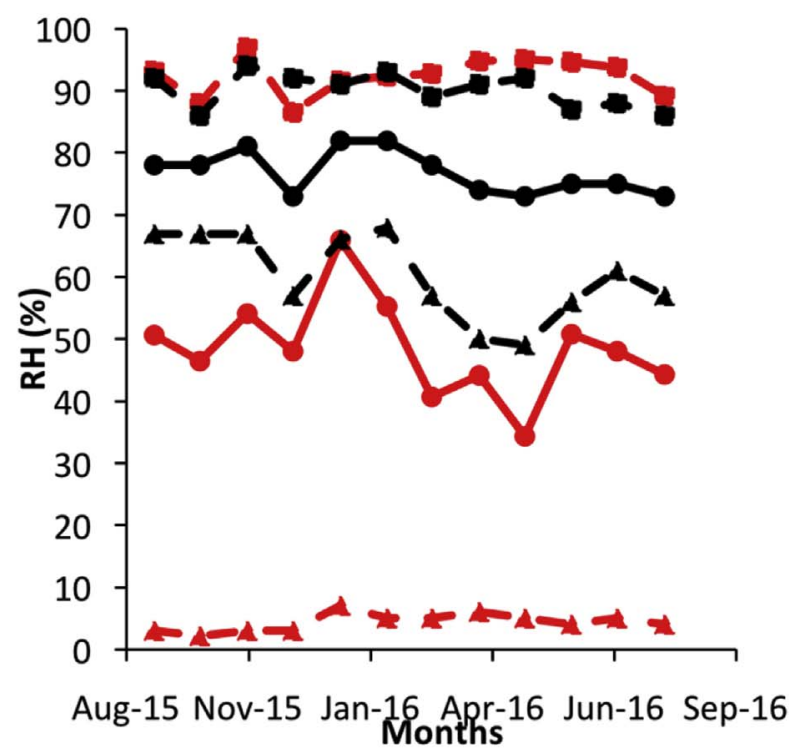

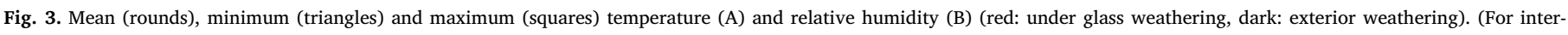
pretation of the references to color in this figure legend, the reader is referred to the Web version of this article.) 


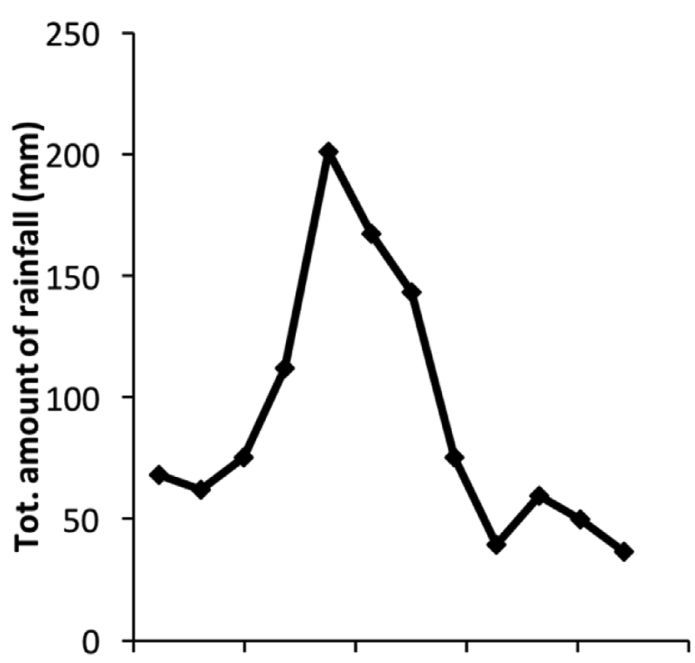

Aug-15 Nov-15 Jan-16 Apr-16 Jun-16 Sep-16
Months

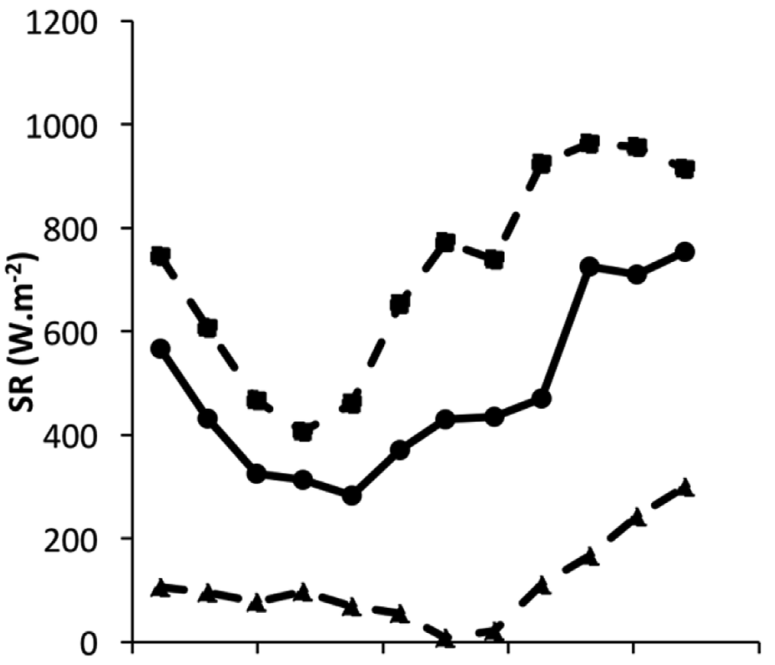

Aug-15 Nov-15 Jan-16 Apr-16 Jun-16 Sep-16

A

B

Fig. 4. Total amount of rainfall (A) and mean (round), minimum (triangles) and instantaneous global solar radiation (SR) values (squares) (B).

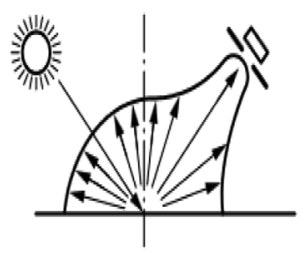

where $\mathrm{M}$ and $\mathrm{N}$ are the number of points along the $\mathrm{X}$ and $\mathrm{Y}$ axes respectively and $z_{x, y}$ is the altitude in $\mu \mathrm{m}$. The mean values and standard deviations were obtained from the analysis of four areas for three samples.

\section{Results and discussion}

\subsection{Mechanical performance}

Stress-strain curves of PP, PP10, and PP30 are plotted in Fig. 6 before and after exterior weathering and under one-year glass weathering as well. At non-weathered state, the stress increased with fiber loading for the same strain value. PP and PP10 presented a continuous increase of stress until $5 \%$ of deformation, whereas the flexural strain at break of PP30 is almost equal to $3.5 \%$. This early break is explained by the stiffness provided by the vegetal fibers. A similar behavior was observed after weathering except for virgin PP that broke after 12 months of exterior weathering at lower stress value (46 MPa) than exteriorly weathered PP30 (71 MPa). This break suggests that the strength of neat PP was more affected by the exterior weathering than by under glass exposition. Although the one-year exposition overthrew the flexural properties of biocomposites, the type of weathering had no significant influence on their mechanical behavior.

The elastic modulus $\mathrm{E}_{\mathrm{f}}$ and the stress at the conventional deflection $\sigma_{\mathrm{fc}}$ have also been recorded during aging and their evolution is represented in Fig. 7.

At non-weathered state, $E_{f}$ increased from $19 \pm 0.15$ to $47 \pm 0.5 \mathrm{GPa}$ with fiber loading. Moreover, the modulus value of biocomposites was higher than that of virgin PP regardless of the weathering state. Thus, the material stiffening effect of the fibers was maintained over the exposition. However, higher significant variations all along the aging were noted for the highest loading with a first moderate increase during the first 2 months of $1 \%$ and $5 \%$ for PP30-EW and PP30-GW, respectively. Therefore, this trend was more noticeable under windshield glass. This increase was followed by a decrease after 12 months which was barely more significant upon exterior exposition of PP30, and seems thus to be more harmful than under glass weathering.

The conventional deflection flexural stress $\sigma_{\mathrm{fc}}$ showed an increase with the fiber rate meaning that the fibers had a reinforcement effect. However, $\sigma_{\mathrm{fc}}$ decreased with the time of exposition whatever the material was due to the degradation of both polymer and hemp fibers. Similar to $E_{f}, \sigma_{\mathrm{fc}}$ of PP30 underwent a higher drop during the first 9 months than PP and PP10 confirming that the presence of vegetal fibers weakened the mechanical stability. Then, $\sigma_{\mathrm{fc}}$ of PP showed a drastic decrease of $18 \%$ after 12 months of exterior weathering while PP30 decreased by $4 \%$ in the last 3 months of exterior exposition. This was certainly due to the rainfall or the exposition to long and short waves of UV-A, B, or C rays that were filtered by laminated windshield glasses to about 98\% [41]. In view of climatic conditions observed between June and August 2016 corresponding to the 10th and 12th months of ageing, it can be assumed that the photo-oxidation of the polymer could mainly be responsible for this embrittlement at the end of the year (Fig. 4). Indeed, this particular three-month period exhibited solar radiation which reached an average value of almost $760 \mathrm{~W} \mathrm{~m}^{-2}$ in the last month. Finally, PP10-EW and PP10-GW evolutions presented less significant differences and variations than PP and PP30.

\subsection{Microstructure}

Since the elastic modulus evolution can be related to the crystallization behavior of the polymer, the crystallinity degree was 

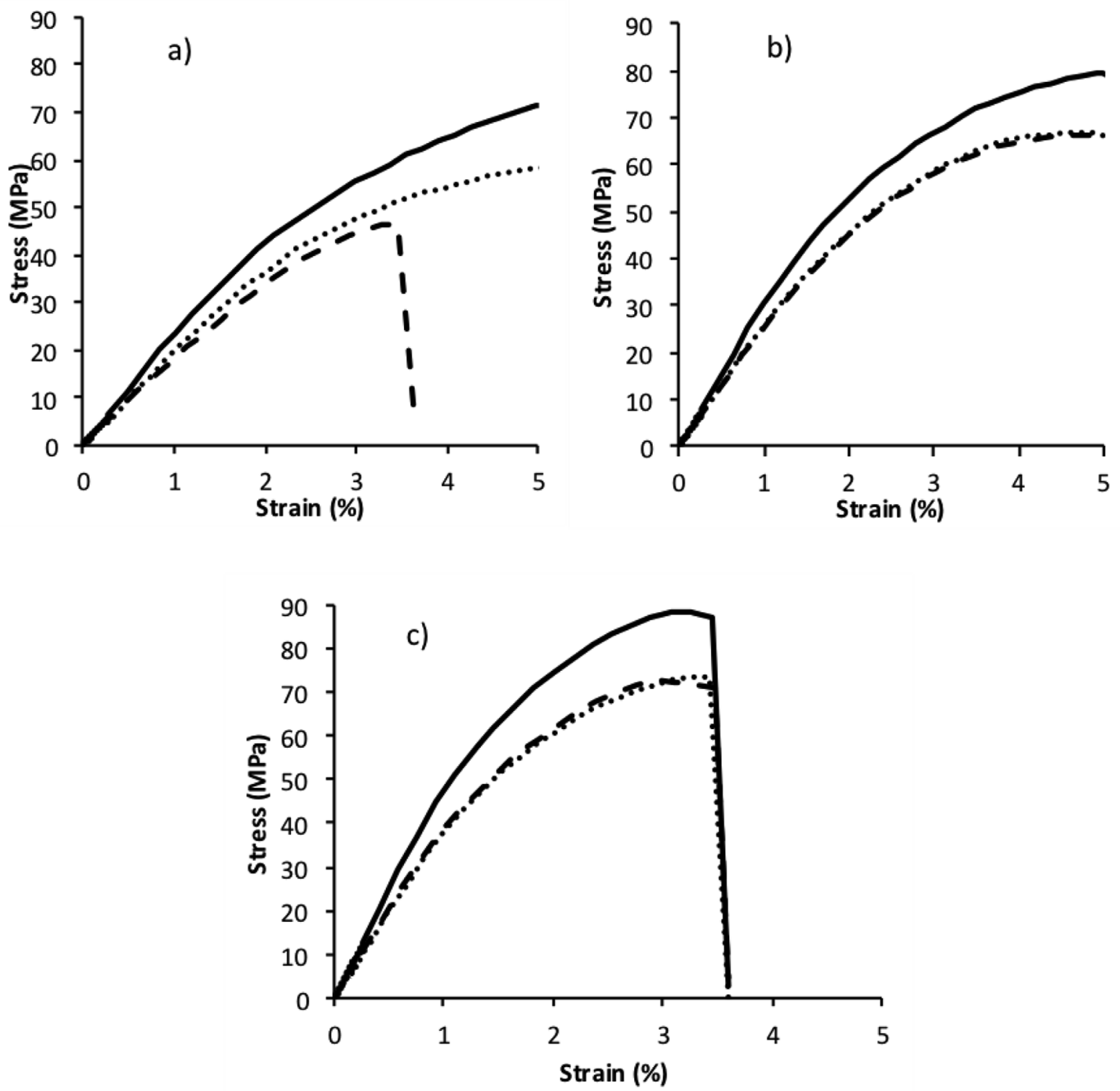

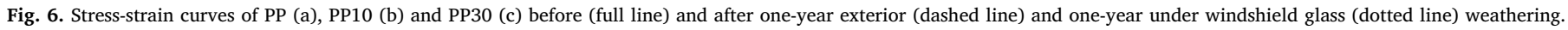

determined by DSC from the first and the second heating ramps (Fig. 8).

Globally, crystallinity percentages of materials are lower for the first heating step than for the second one. Moreover, at non-weathered state, PP30 exhibited $\chi_{\mathrm{c} 1}$ and $\chi_{\mathrm{c} 2}$ crystallinity rates higher by $2 \%$ and $4 \%$, respectively than virgin PP. A similar increase with the fiber content of the crystallinity percentage of polymer matrices deduced from the first $[3,42]$ and the second heating ramp [43,44] was observed at initial state. This implies that lignocellulosic compounds played the role of nucleating agents favouring the crystallization of the polymer $[44,45]$.

Moreover, the evolution of the crystallinity rate over the weathering shows that the exposition did not have considerable influence on PP and PP10. However, PP30 underwent higher variations with a slight increase after 2 months and a decrease during the following 10 months of weathering. Indeed, this primary increase is more important for the highest reinforced fiber composite suggesting that the nucleation effect of the fibers improved the crystallinity rate [24]. This increase was more significant under windshield glass where temperatures reached almost $90^{\circ} \mathrm{C}$. Regarding under glass weathered PP30, the values increased by $11 \%$ for $\chi_{\mathrm{c} 1}$ against $9 \%$ for $\chi_{\mathrm{c} 2}$. So a similar trend as Young's modulus evolution was registered. It is ascribed to the polymer chemicrystallization in the amorphous phase which is favored under high temperatures due to the reduction of the length of the macromolecular chains inducing their higher mobility [46]. Exterior exposition generally induced a higher drop of $\chi_{c}$ than under glass weathering, especially for $\chi_{\mathrm{c} 2}$ during the last 10 months of ageing. Indeed, $\chi_{\mathrm{c} 1}$ and $\chi_{\mathrm{c} 2}$ of PP30-EW decreased by $20 \%$ and $23 \%$, respectively whereas it declined by 3 and $6 \%$ for PP30-GW. However, no significant difference was noted between $\chi_{\mathrm{c} 1}$ and $\chi_{\mathrm{c} 2}$ evolution tendencies.

\subsection{Chemical structure}

The evolution of the infrared peaks of carbonyl groups such as $\gamma$ lactones $\left(1780 \mathrm{~cm}^{-1}\right)$, esters and aliphatic aldehydes $\left(1740 \mathrm{~cm}^{-1}\right)$, carboxylic acids and ketones $\left(1711 \mathrm{~cm}^{-1}\right)$ specific to oxidative degradation and ethenyl functional groups $\left(1650 \mathrm{~cm}^{-1}\right)$ of polymers and fibers chain scissions are depicted in Fig. 9 before and after a one-year exposition $[9,40,47]$. The spectra were zoomed in the of-interest wavenumber range $1490-1820 \mathrm{~cm}^{-1}$. Before weathering, the increase in the intensity of absorption bands assigned to $\mathrm{C}=\mathrm{O}$ and $\mathrm{C}=\mathrm{C}$ bonds vibration with the fiber loading was due to the natural presence of carbonyl and carbon double bonds in holocellulose and lignin $[48,49]$.

During weathering, the continuous linear increase in the intensity of 

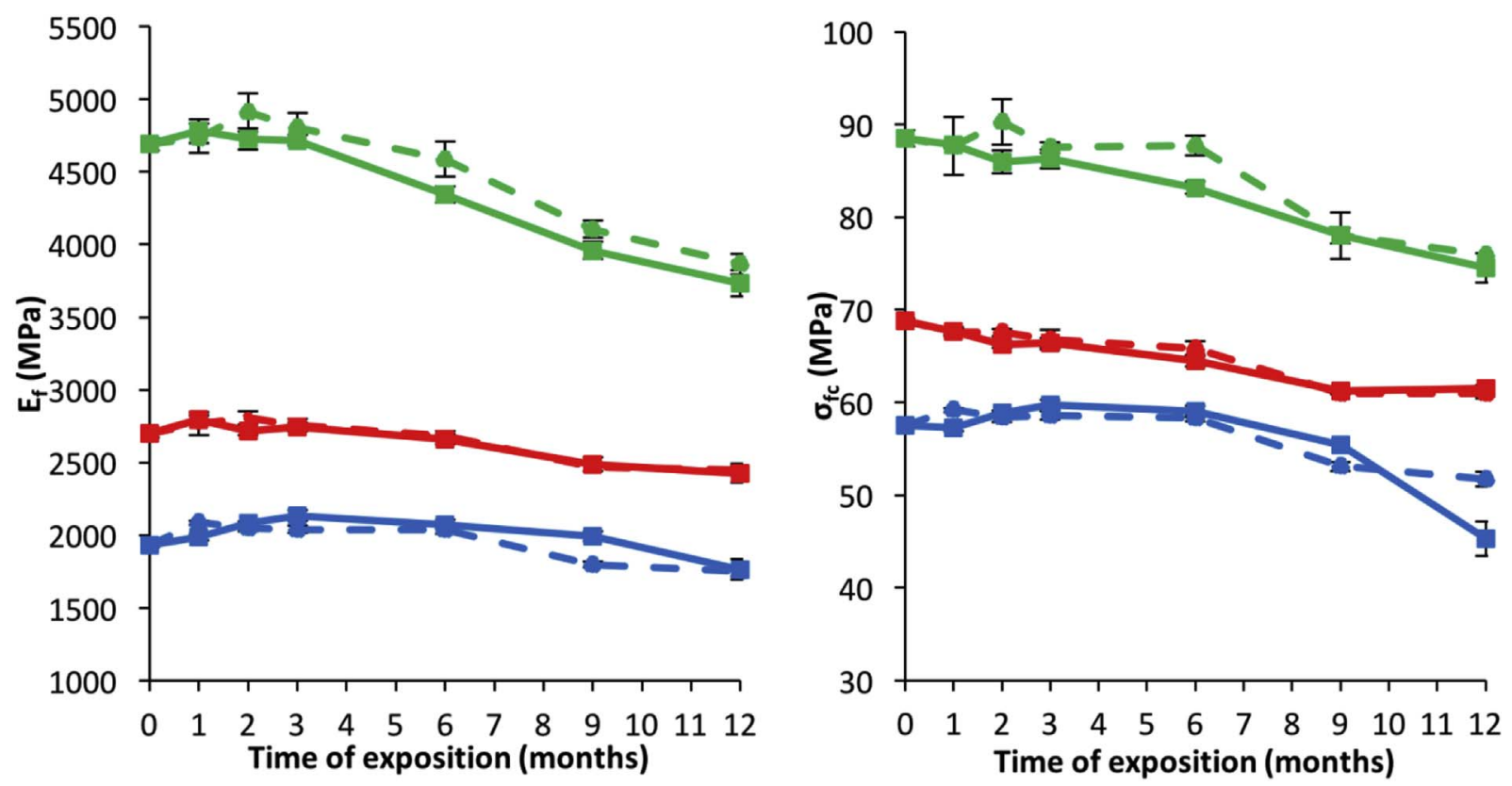

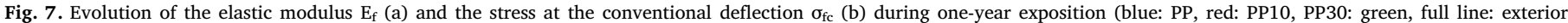
weathering, dashed line: under glass weathering). (For interpretation of the references to color in this figure legend, the reader is referred to the Web version of this article.)
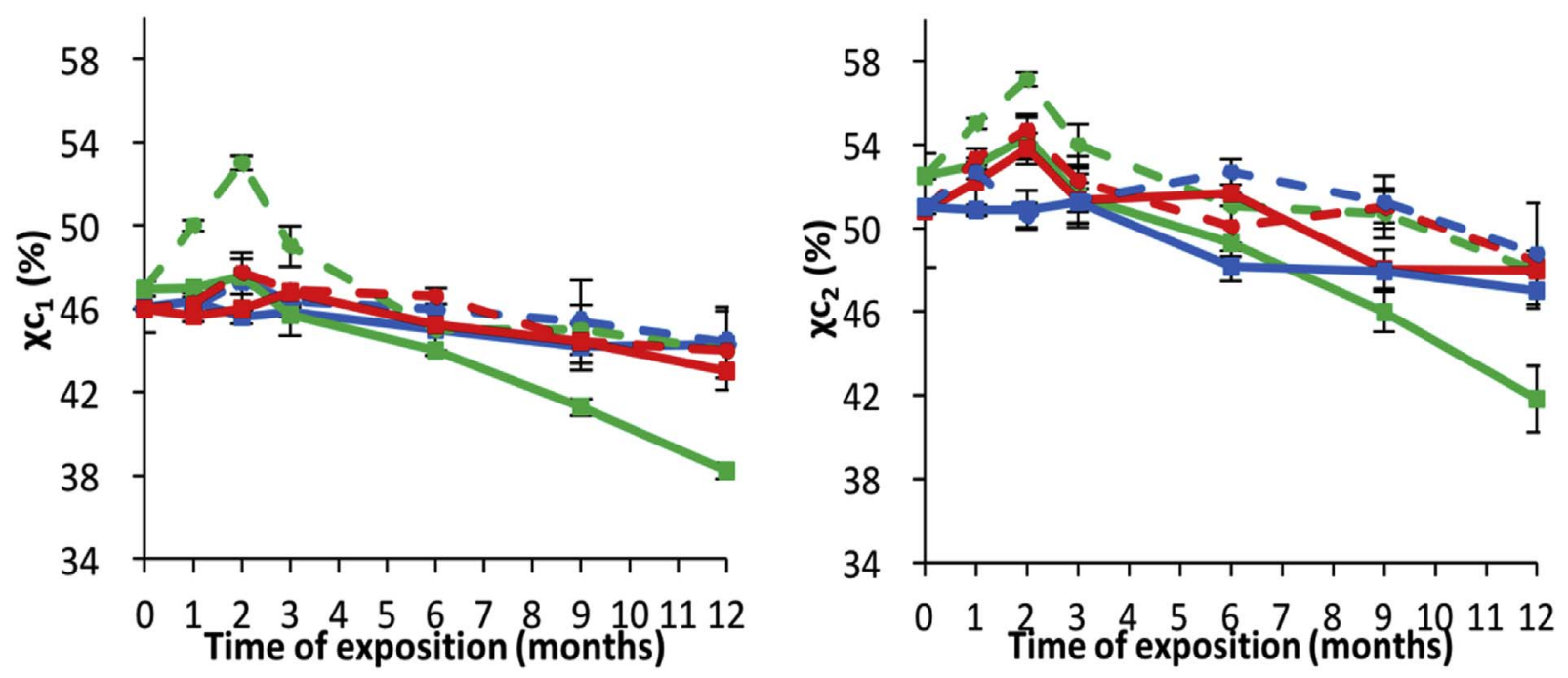

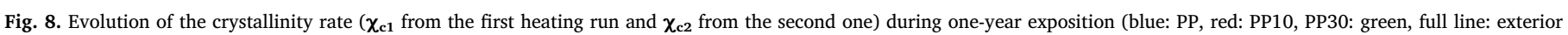
weathering, dashed line: under glass weathering). (For interpretation of the references to color in this figure legend, the reader is referred to the Web version of this article.)

carboxylic acids and esters absorbance on the PP spectrum mainly indicates a photo and thermo-oxidative degradation of the polymer under UV rays and high temperatures (Fig. 10) involving the reaction with oxygen from the atmosphere. Regarding $\gamma$-lactones, the absorbance did not vary a lot during the first 6 months. Then it suddenly rose up from 0.02 to 0.16 in 6 months. The carbonyls absorbance increase was more drastic for biocomposites which suggests that hemp fibers also underwent photo and thermo-oxidation. The proportion of vegetal fibers at the surface exceeding the PP proportion over the ageing due to a polymer decomposition could also contribute to this increase. Among all the derivatives containing carbonyl groups, ketones and carboxylic acids were preferentially formed during weathering contrary to nonweathered state. It is that the hydrolysis of esters products occurred and led to the formation of carboxylic acids. Moreover, this characterization allowed to highlight that opposite to carbonyl concentration which presented a similar evolution under the two types of weathering, the exterior ageing promoted a greater generation of carbon double bonds than under glass one. This trend was more visible for weathered PP10 and PP30 implying that the vegetal fibers contributed to the $\mathrm{C}=\mathrm{C}$ bonds formation. The increasing protrusion of fibers on surface, including lignin containing aromatic ring-based structure, may involve the $\mathrm{C}=\mathrm{C}$ stretching detection [3]. Also, their increasing formation during the first 6 months might be favored by hydrolytic effect of increasing heavy rainfall during this period (Fig. 4) leading to chain scissions along the early exposition. Otherwise, the evolution of vinyl was stabilized after 6 months regardless of the weathering conditions, especially for biocomposites. The conversion of $\mathrm{C}=\mathrm{C}$ towards $\mathrm{C}=\mathrm{O}$ groups via Norrish type II reaction may explain this formed plateau [10]. Moreover, the increasing temperature and solar radiation observed during this stage could encourage their conversion. 

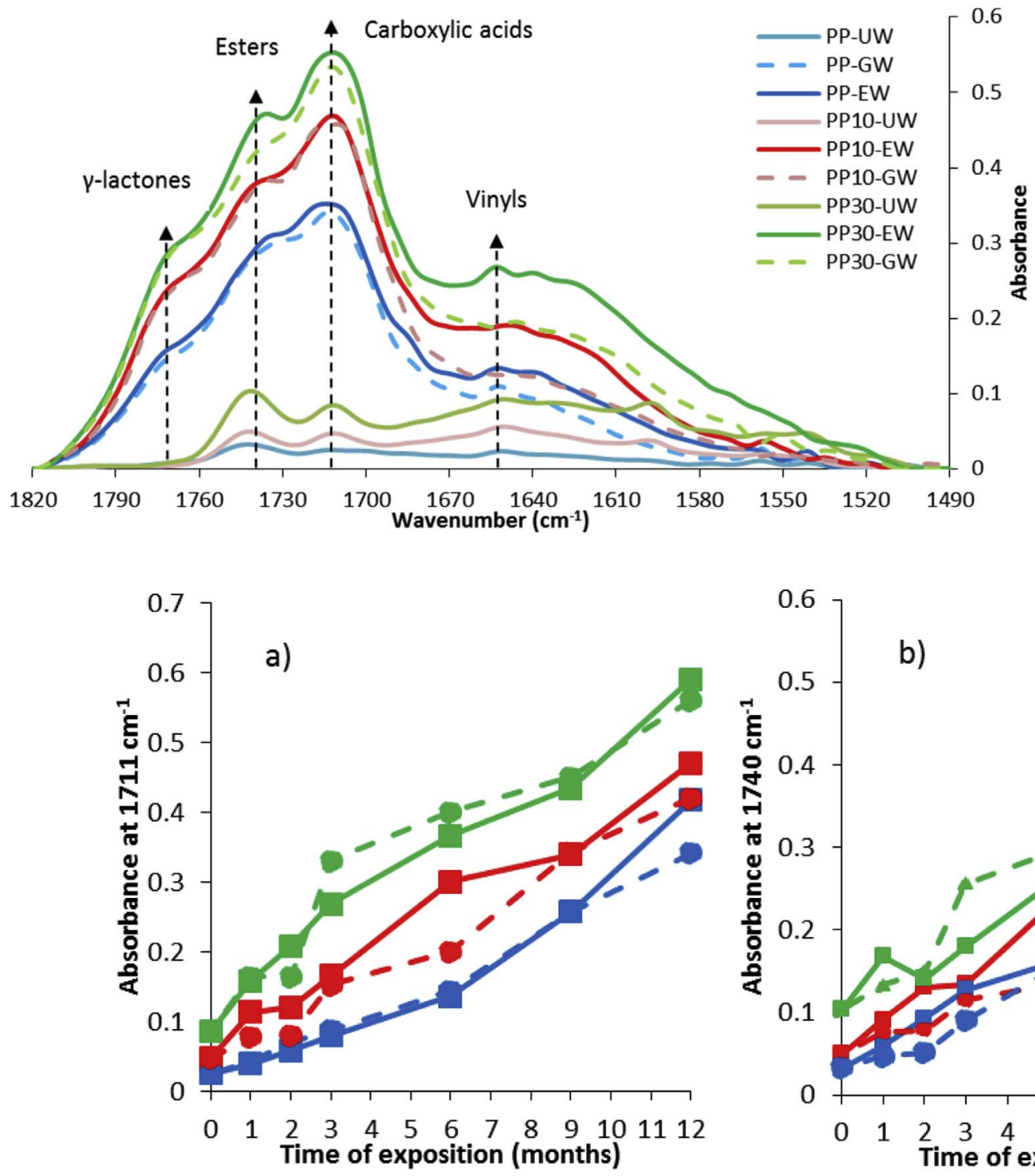

Fig. 9. Infrared spectra of unweathered and oneyear weathered PP (blue based spectra), PP10 (red based spectra) and PP30 (green based spectra) in $1490-1820 \mathrm{~cm}^{-1}$ region. (For interpretation of the references to color in this figure legend, the reader is referred to the Web version of this article.)
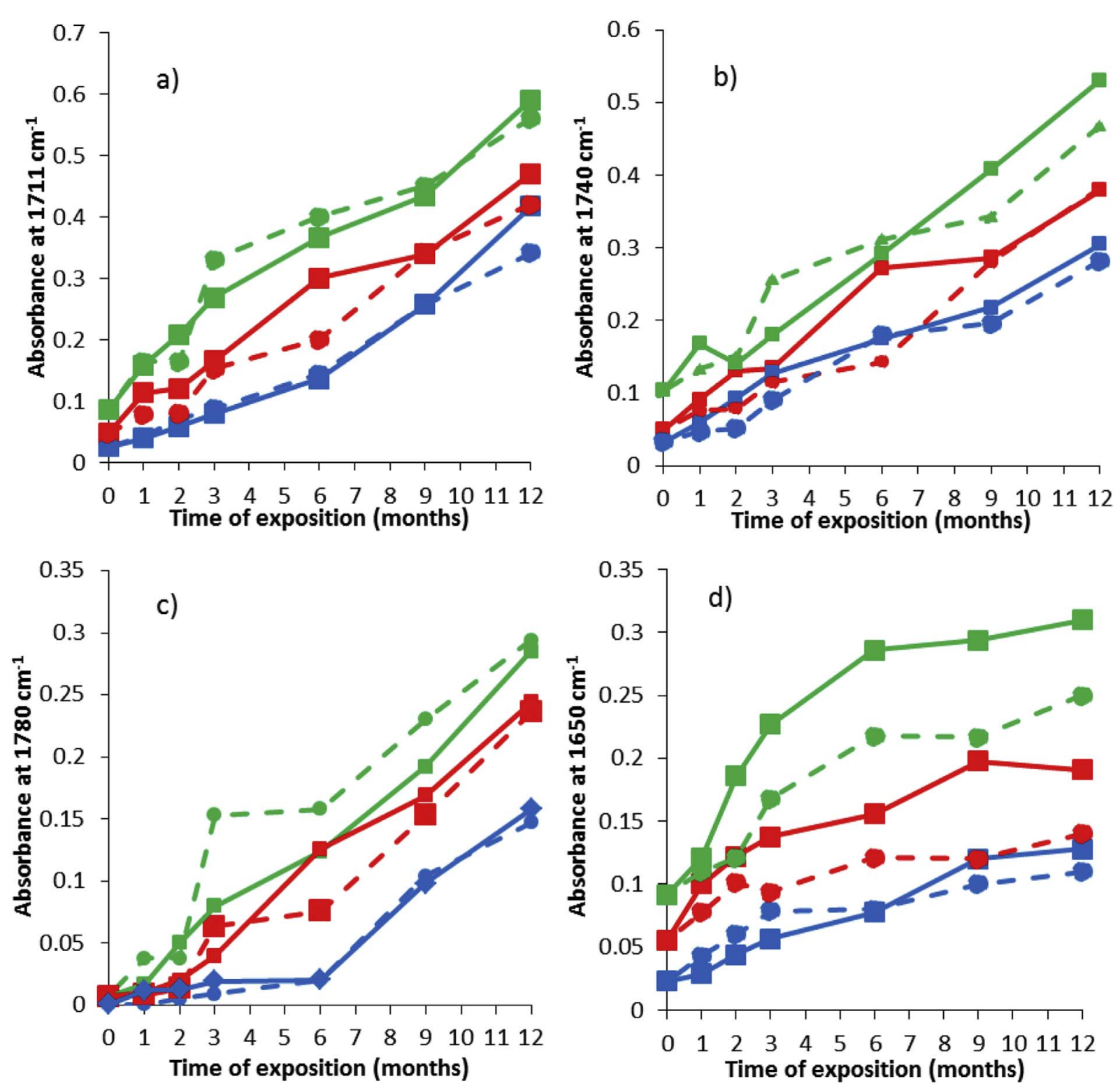

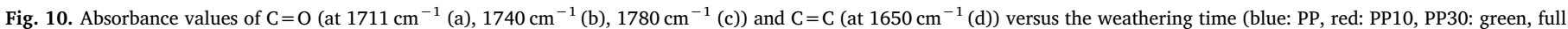

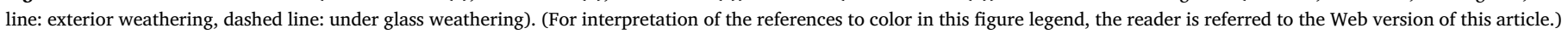




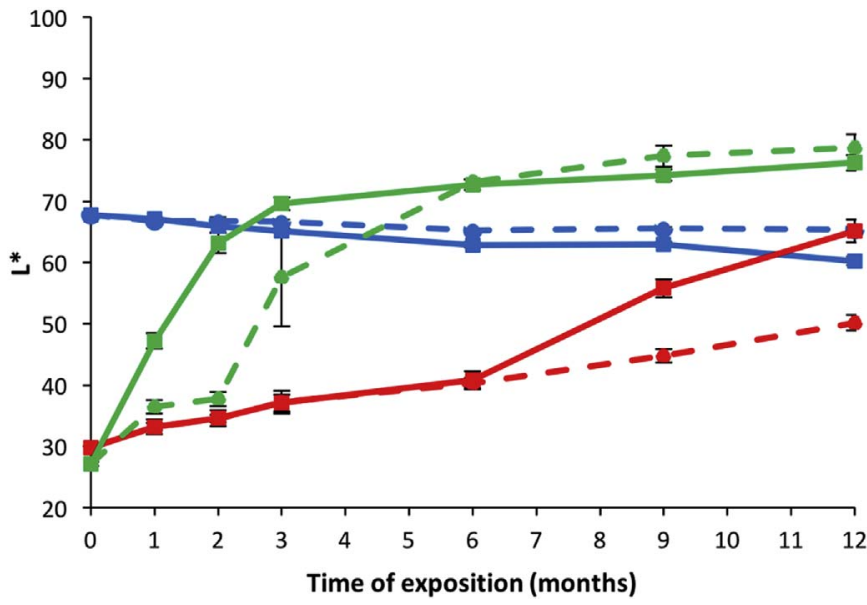

Fig. 11. $L^{*}$ coordinate evolution over weathering (blue: PP, red: PP10, PP30: green, full line: exterior weathering, dashed line: under glass weathering). (For interpretation of the references to color in this figure legend, the reader is referred to the Web version of this article.)

\subsection{Visual aspect}

\subsubsection{Color}

Contrary to virgin PP, weathering had a great impact on biocomposites lightness evolution (Fig. 11). Indeed, the lightness of PP30 varied in a wide range of $\mathrm{L}^{*}$ values in the first months, at which the bleaching kinetics were higher for exterior weathering than for under windshield glass exposition. The degradation of lignin is responsible for this bleaching and it is also explained by the reduction mechanism of paraquinone to hydroquinone molecules under the effect of UV radiation [3]. Then, $\mathrm{L}^{*}$ remained constant after 12 months. Indeed, PP30 reached a maximum $L^{*}$ coordinate of approximately 75 after 3 months of exterior weathering and 6 months of under glass weathering. This lightness saturation is in agreement with previous color studies of reinforced natural fibers plastic composites $[8,22,50,51]$. Here, it is assumed to be due to the increasing proportion of holocellulose at the surface which is completely uncovered after the second half of the year.

The color was monitored during the two types of weathering and the coordinates $\mathrm{a}^{*}$ and $\mathrm{b}^{*}$ are represented in the chromatic plane in Fig. 12 for each material and at each weathering state. First, this graph clearly shows that three main groups can be formed by the material.

Second, biocomposites experienced higher variations in color than $\mathrm{PP}$, in particular by yellowing. Moreover, under glass weathering

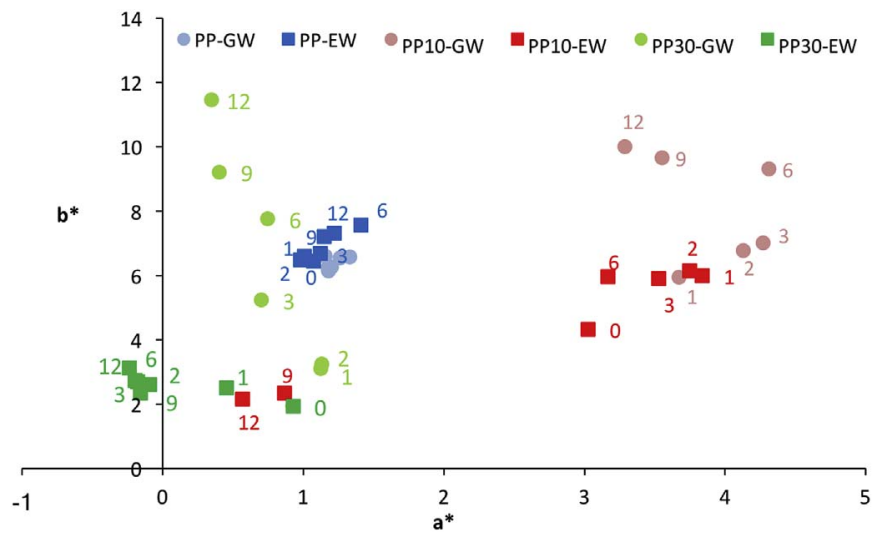

Fig. 12. $\mathrm{a}^{*}$ and $\mathrm{b}^{*}$ chromatic coordinates evolution over weathering (the numbers corresponding to the time of exposition (months)) (blue: PP, red: PP10, green: PP30, darker colors: exterior weathering, clearer colors: under glass weathering). (For interpretation of the references to color in this figure legend, the reader is referred to the Web version of this article.) implied a higher yellowing kinetics than exterior exposition. For instance, b* of PP30-GW increased by 10 units whereas it only increased by 1 unit after one-year of exterior exposition. This was certainly due to the higher temperatures under glass. As well as for the bleaching, this yellowing was due to the decomposition of the lignin structure present in hemp fibers into paraquinones whose characteristic color is yellow. Thus, the increase in temperature may favor the formation of paraquinones, which were consequently favored during under glass ageing, and the redox cycle previously mentioned might be shifted towards the oxidation of hydroquinones to paraquinones. However, as mentioned in the introductory part, holocellulose contained at high rate in long-time retted hemp fibers, could undergo yellowing due to its oxidation. Indeed, hemicelluloses, thermally sensitive substances, may preferentially oxidize and thus become yellow faster under high temperature than under UV radiation. Regarding a* evolution, its decrease witnessed a loss of red color of biocomposites due to orthoquinones or phenolic extractives degradation [52]. Otherwise, PP10 was particularly subjected to the red color loss after 9 and 12 months of exterior ageing, the stage during which temperatures and UV radiation were the highest. So the exterior weathering promoted a* decrease whereas the under glass exposure promoted $\mathrm{b} *$ increase. This observation leads to presume that chromophoric yellowing structures are sensitive to high temperatures whereas UV rays and water absorption could induce reddish quinones and extractives decomposition.

\subsubsection{Gloss}

The intensity of the light reflected by non-weathered and one-year weathered materials is represented as a function of the angle of detection in Fig. 13. Focusing on the non-weathering state, the maximum intensity of the specular peak decreased with the hemp fibers rate. This means that gloss diminished with the fiber loading because of the presence of hemp fibers at the surface leading to a less smooth surface [12]. Otherwise, the intensity of the peak decreased by 5 times between PP10 and PP30. Moreover, the specular peak of the highest fiber loaded composite is extended on a wider range of detection angles than PP and PP10, and demonstrates a more diffuse reflection of the light induced in the presence of the fibers.

For PP, PP10 and PP30 weathered samples, the specular peak becomes wider and extended on several angles. PP underwent a relatively great decrease of gloss after exterior weathering: the maximum intensity decreasing by almost 5 times in one year. The specular peak of exterior and under glass weathered PP30 was hardly visible. It primarily suggests that the exposition induced a loss of surface matter which has an effect on the brightness. The next part will permit to analyze the surface aspect. Also, it can be assumed that hemp fibers were partly responsible for the surface aspect alteration. The asymmetric repartition of the light intensity according to $-20^{\circ}$ can be explained by the non-flat surface of biocomposites.

The variations of $G_{1}$ and $G_{2}$ values are displayed in Fig. 14 for all materials. The influence of the type of weathering was mainly observed for neat PP all along the ageing whose gloss was mostly impacted by the exterior parameters such as UV rays or rainfall more than extreme temperatures. The loss of gloss of neat PP-EW could originate from the dust and other impurities deposits and the formation of microcracks issued from the degradation of the polymer. With respect to biocomposites, the degradation of both hemp fibers and the polymer matrix at the surface induced a drop of both $G_{1}$ and $G_{2}$. Gloss values of PP30-EW and PP30-GW tended towards a minimum $\mathrm{G}_{1}$ and $\mathrm{G}_{2}$ ratio of 1 at an early stage of weathering demonstrating their severe impact on the biocomposite gloss. Moreover, $\mathrm{G}_{1}=44$ of non-weathered PP10 was close to that of PP30 $\left(G_{1}=12\right)$ while $G_{2}$ value decreased from 2418 for PP10 to 30 for PP30. This means that the specular peak shape of PP10 is close to that of PP30. Otherwise, the non-flat surface could be responsible for the high values of standard deviations. 

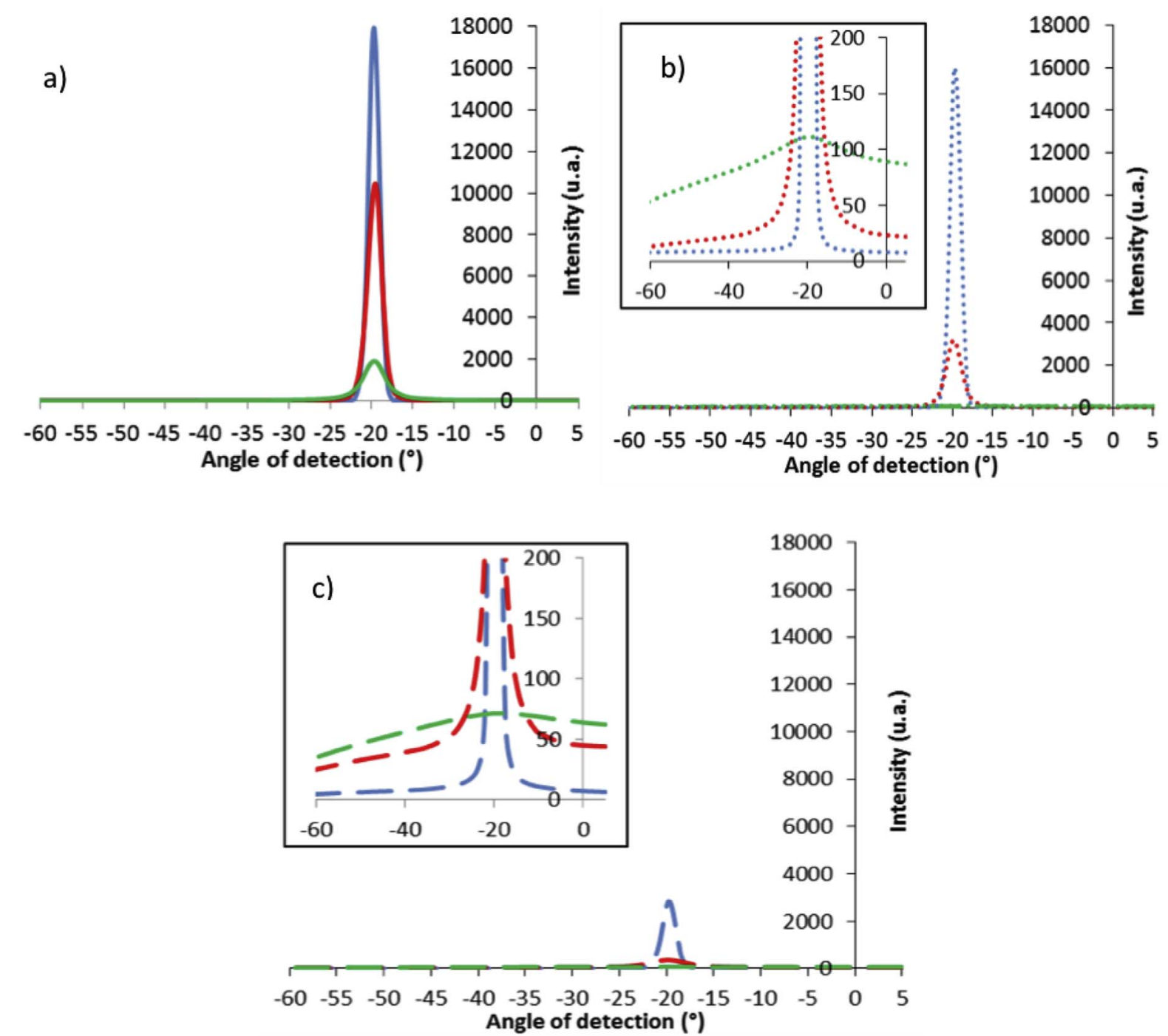

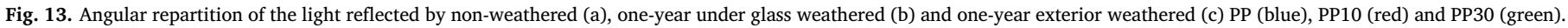
(For interpretation of the references to color in this figure legend, the reader is referred to the Web version of this article.)

\subsection{Topography}

\subsubsection{Roughness}

Since the gloss is related to the surface aspect, the roughness has been qualitatively and quantitatively assessed to understand the gloss variations. The surface images are gathered in Table 4 . Altitudes variations are represented by false colors. It is worth noting that the difference in color between images should not be taken into account. Before weathering, materials exhibited a relative smooth surface. Then, regular microcracks were distinguished at the surface of exterior weathered neat PP. Moreover, these microcracks followed the same direction of the flowing injected matter during molding processing regardless of the used specimen of virgin PP-EW. This indicates that the processing step had an influence on materials stability over the weathering. The polymer matrix was probably weakened by macromolecular chain scissions [53] and these microcracks could contribute to the embrittlement of PP. PP10-EW presented both microcraks and some hollows that are probably issued from the removal of vegetal fibers due to exterior factors; however, the topography of PP10-GW was not significantly influenced by the ageing. Weathered PP30 surface presented more and deeper slots than other materials. So the presence of fibers damaged the surface of the reinforced material.

The changes in average roughness parameter Sa are shown in
Fig. 15. Before ageing Sa increased from $0.45 \pm 0.33 \mu \mathrm{m}$ for PP to $1.89 \pm 0.54 \mu \mathrm{m}$ for PP30 since the presence of vegetal fibers at the biocomposites surface led to a less smooth surface [12]. This observation corroborates with the gloss measurement. After exposition, no significant variation of Sa was observed for PP during 9 months. Then the roughness parameter of exterior weathered PP increased from $0.31 \pm 0.14 \mu \mathrm{m}$ to $1.98 \pm 0.22 \mu \mathrm{m}$ in 3 months whereas it remained at the same roughness level under windshield glass. This may be explained by the increasing solar radiation during this period which is responsible for photo-oxidation inducing polymer chain scission and creating thereby surface cracks [9]. Also, this trend is in agreement with the evolution of the stress at the conventional deflection and the appearance of these cracks on surface may decrease the mechanical resistance. Nevertheless, the formation of these microcracks was expected to occur on surfaces of under glasses weathered samples since the crystallinity rate mostly increased at the beginning of exposition due to chain scission. But these microcracks were only distinguished for exterior weathered samples. This could be linked to rainfall and UV rays synergetic effects accelerating the degradation of the polymer after the first short two-month period favoring microcracks for outdoor exposed materials. Sa values of biocomposites exhibited a cubic continuous growth. This increase was due to the degradation of the polymer matrix and fibers inducing an appearance of fibers on the surface. Also, a water 

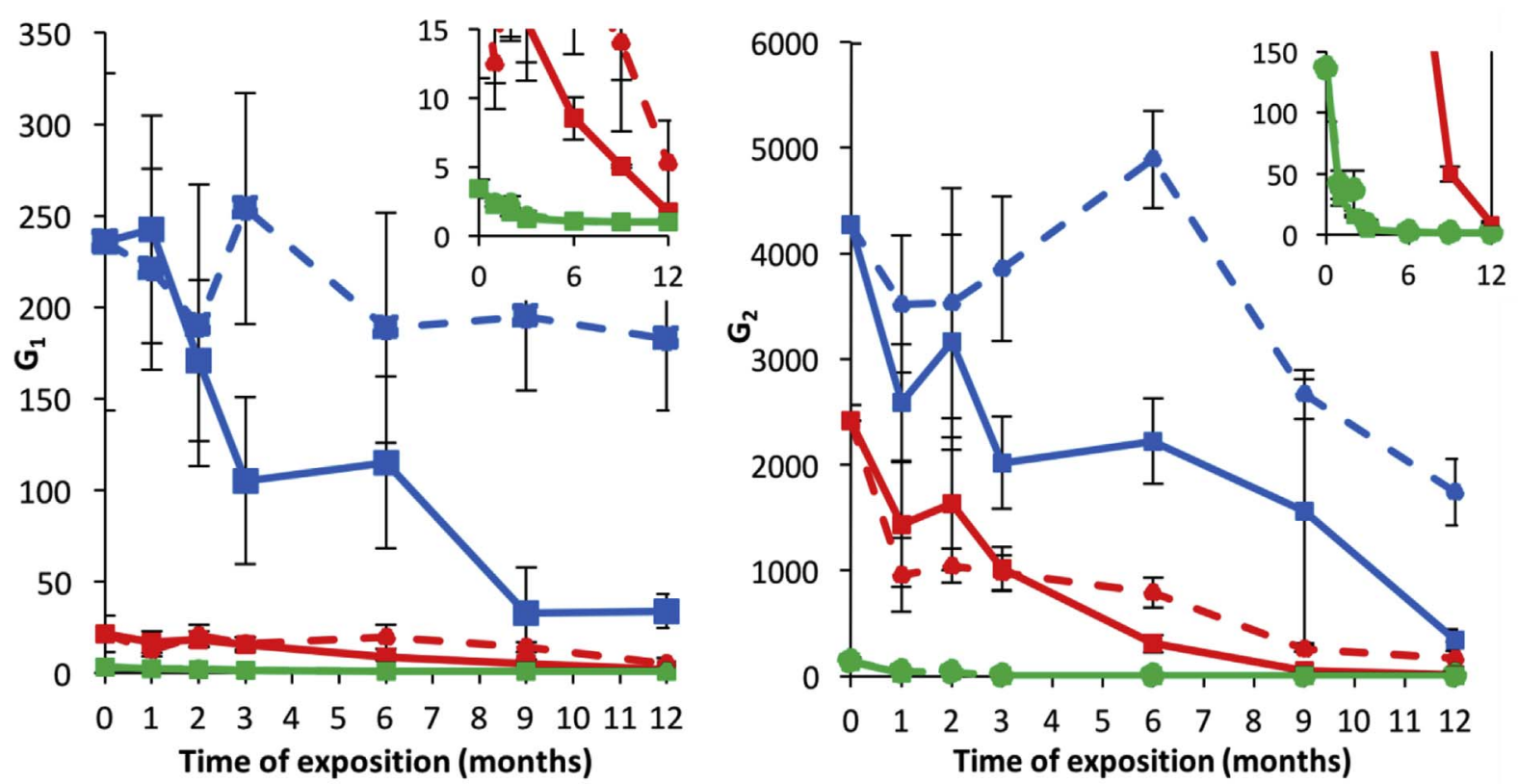

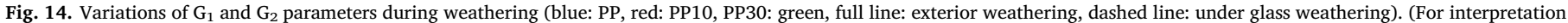
of the references to color in this figure legend, the reader is referred to the Web version of this article.)

Table 4

Altitude images of surfaces of non-weathered and one-year weathered PP, PP10 and PP30.

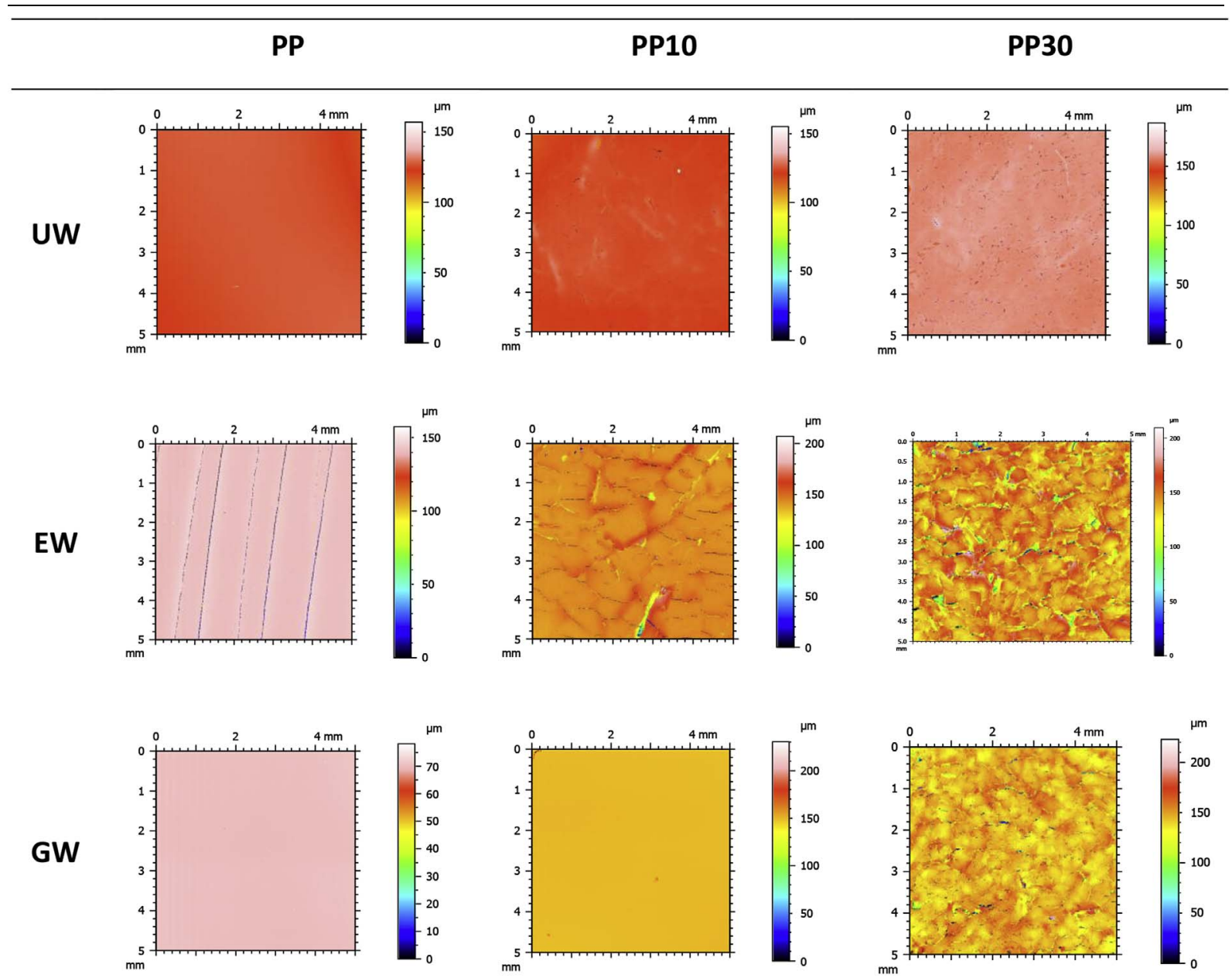




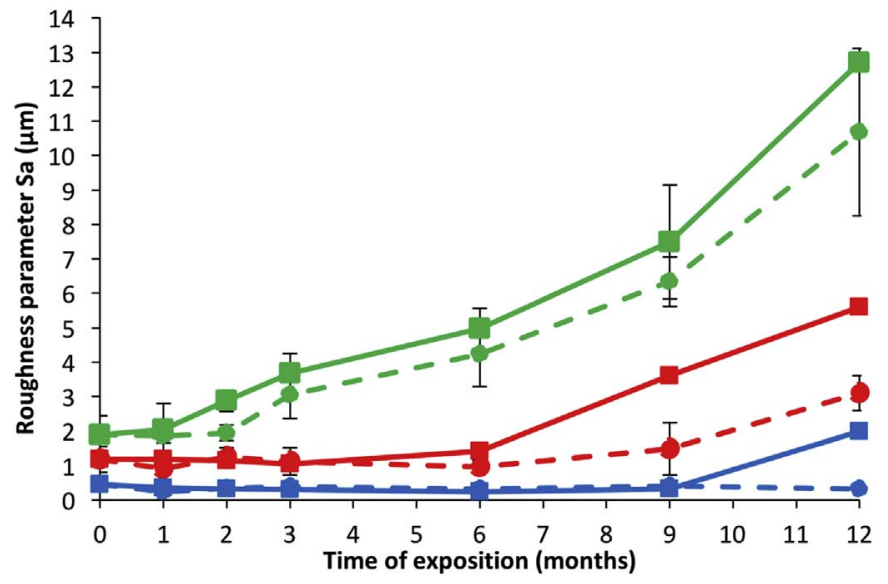

Fig. 15. Sa roughness parameter evolution over the exposition (blue: PP, red: PP10, PP30: green, full line: exterior weathering, dashed line: under glass weathering). (For interpretation of the references to color in this figure legend, the reader is referred to the Web version of this article.)

uptake could provoke fiber-matrix debonding despite the presence of coupling agent. Contrary to other studied properties, PP10-EW and PP10-GW did not exhibit similar evolutions. Indeed, Sa of the intermediate loading biocomposite that was exteriorly weathered increased faster from February to August 2016.

\section{Conclusion}

The objective of this work was to understand the influence of the type of weathering (exterior versus under glass weathering) on PP and $\mathrm{PP} /$ hemp fibers biocomposites (10 and $30 \mathrm{wt} \%$ ) properties such as mechanical, chemical, microstructural and visual aspect properties.

Biocomposites modulus were less stable than PP over the whole weathering period regardless of the kind of exposition. Ageing induced stronger changes of conventional deflection stress for PP30 than for PP during the first 9 months of weathering. Then, the stress at the conventional deflection decreased drastically by $18 \%$ for exteriorly aged PP whereas it slightly decreased for exteriorly aged PP30. Hence, PP was certainly highly sensitive to high UV light intensity at this stage of exposition which highly deteriorated the polymer.

Coming to chemical and microstructural properties, a higher degradation rate of chemical structure was recorded for PP30. This suggests that either lignocellulosic compounds appeared at the surface or hemp fibers oxidized faster. Moreover, even if the increase in carbonyl species level during the ageing was not influenced by the type of weathering, the exterior weathering favored more the formation of vinyl species and decreased crystallinity rate. This latter is caused by synergetic effect of solar radiation and rainfall.

Physical properties variations are also more noticeable for biocomposites than for PP because of the hemp fibers sensitivity to climatic conditions. However, even if they bleached at the same level under the two types of exposition, some differences in color variations were observed for weathered biocomposites, especially yellowing during under glass ageing and red color loss during exterior ageing. This was explained by the possible different sensitivities of the fibers components under rain, UV rays and high temperatures. Ageing also highly altered the surface aspect (gloss, roughness). The assessment of gloss parameters allowed to understand the contribution of the presence of hemp fibers to the reflection in the specular or diffuse zones.

PP10 material constitutes a good compromise in terms of mechanical performance and visual aspect changes. Indeed, its mechanical performance was enhanced compared to neat PP. Moreover, this material underwent lower variations (in terms of bleaching and yellowing) than PP30. All these properties will be faced together in a next work to bring out relationships.

\section{Acknowledgements}

This research did not receive any specific grant from funding agencies in the public, commercial, or not-for-profit sectors.

\section{References}

[1] G. Marsh, Next step for automotive materials, Mater. Today 6 (2003) 36-43, http:// dx.doi.org/10.1016/S1369-7021(03)00429-2.

[2] X. Zhou, S. Huang, L. Chen, Effect of antiaging agents on the outdoor natural weathering of bamboo powder/polypropylene foamed composites, J. Vinyl Addit. Technol. 22 (2014) 311-319, http://dx.doi.org/10.1002/vnl.21433.

[3] L. Soccalingame, D. Perrin, J.-C. Bénézet, A. Bergeret, Reprocessing of UV-weathered wood flour reinforced polypropylene composites: study of a natural outdoor exposure, Polym. Degrad. Stabil. 133 (2016) 389-398, http://dx.doi.org/10.1016/ j.polymdegradstab.2016.09.011.

[4] N. Le Moigne, M. Longerey, J.-M. Taulemesse, J.-C. Bénézet, A. Bergeret, Study of the interface in natural fibres reinforced poly(lactic acid) biocomposites modified by optimized organosilane treatments, Ind. Crop. Prod. 52 (2014) 481-494, http:// dx.doi.org/10.1016/j.indcrop.2013.11.022.

[5] Platts petrochemical Analytics, Report: Global Polyolefins Outlook: 2014-2025, (2016) www.platts.com/ppa , Accessed date: 16 June 2017.

[6] L. Belec, T.H. Nguyen, D.L. Nguyen, J.F. Chailan, Comparative effects of humid tropical weathering and artificial ageing on a model composite properties from nano- to macro-scale, Compos. Part A Appl. Sci. Manuf 68 (2015) 235-241, http:// dx.doi.org/10.1016/j.compositesa.2014.09.028.

[7] M.Z. Ahmad Thirmizir, Z.A. Mohd Ishak, R. Mat Taib, S. Rahim, S. Mohamad Jani, Natural weathering of kenaf bast fibre-filled poly(butylene succinate) composites: effect of fibre loading and compatibiliser addition, J. Polym. Environ. 19 (2010) 263-273, http://dx.doi.org/10.1007/s10924-010-0272-2.

[8] S. Butylina, M. Hyvärinen, T. Kärki, A study of surface changes of wood-polypropylene composites as the result of exterior weathering, Polym. Degrad. Stabil. 97 (2012) 337-345, http://dx.doi.org/10.1016/j.polymdegradstab.2011.12.014.

[9] J.S. Fabiyi, A.G. McDonald, M.P. Wolcott, P.R. Griffiths, Wood plastic composites weathering: visual appearance and chemical changes, Polym. Degrad. Stabil. 93 (2008) 1405-1414, http://dx.doi.org/10.1016/j.polymdegradstab.2008.05.024.

[10] N.M. Stark, L.M. Matuana, Surface chemistry changes of weathered HDPE/woodflour composites studied by XPS and FTIR spectroscopy, Polym. Degrad. Stabil. 86 (2004) 1-9, http://dx.doi.org/10.1016/j.polymdegradstab.2003.11.002.

[11] M.D.H. Beg, K.L. Pickering, Accelerated weathering of unbleached and bleached Kraft wood fibre reinforced polypropylene composites, Polym. Degrad. Stabil. 93 (2008) 1939-1946, http://dx.doi.org/10.1016/j.polymdegradstab.2008.06.012.

[12] C. Badji, L. Soccalingame, H. Garay, A. Bergeret, J.-C. Bénézet, Influence of weathering on visual and surface aspect of wood plastic composites: correlation approach with mechanical properties and microstructure, Polym. Degrad. Stabil. 137 (2017) 162-172, http://dx.doi.org/10.1016/j.polymdegradstab.2017.01.010.

[13] M.I. Popa, S. Pernevan, C. Sirghie, I. Spiridon, D. Chambre, D.M. Copolovici, N. Popa, Mechanical properties and weathering behavior of polypropylene-hemp shives composites, J. Chem. 2013 (2013) 1-8, http://dx.doi.org/10.1155/2013/ 343068.

[14] M. Muasher, M. Sain, The efficacy of photostabilizers on the color change of wood filled plastic composites, Polym. Degrad. Stabil. 91 (2006) 1156-1165, http://dx. doi.org/10.1016/j.polymdegradstab.2005.06.024.

[15] A. Bergeret, J. Benezet, T.P.T. Tran, G.C. Papanicolaou, A. Koutsomitopoulou, Valorization of agricultural by-products in poly (lactic acid) to develop biocomposites, in: V.K. Thakur (Ed.), Green Compos. From Nat. Resour, CRC Press, Taylor \& Francis LLC, 2013, , http://dx.doi.org/10.13140/2.1.1271.2969.

[16] M.S. Islam, K.L. Pickering, N.J. Foreman, Influence of accelerated ageing on the physico-mechanical properties of alkali-treated industrial hemp fibre reinforced poly(lactic acid) (PLA) composites, Polym. Degrad. Stabil. 95 (2010) 59-65, http:// dx.doi.org/10.1016/j.polymdegradstab.2009.10.010.

[17] M.M. Thwe, K. Liao, Durability of bamboo-glass fiber reinforced polymer matrix hybrid composites, Compos. Sci. Technol. 63 (2003) 375-387, http://dx.doi.org/ 10.1016/S0266-3538(02)00225-7.

[18] O. Gil-Castell, J.D. Badia, T. Kittikorn, E. Strömberg, A. Martínez-Felipe, M. Ek, S. Karlsson, A. Ribes-Greus, Hydrothermal ageing of polylactide/sisal biocomposites. Studies of water absorption behaviour and Physico-Chemical performance, Polym. Degrad. Stabil. 108 (2014) 212-222, http://dx.doi.org/10.1016/j. polymdegradstab.2014.06.010.

[19] A. Le Duigou, P. Davies, C. Baley, Seawater ageing of flax/poly(lactic acid) biocomposites, Polym. Degrad. Stabil. 94 (2009) 1151-1162, http://dx.doi.org/10. 1016/j.polymdegradstab.2009.03.025.

[20] A. Arbelaiz, B. Fernández, J.A. Ramos, A. Retegi, R. Llano-Ponte, I. Mondragon, Mechanical properties of short flax fibre bundle/polypropylene composites: influence of matrix/fibre modification, fibre content, water uptake and recycling, Compos. Sci. Technol. 65 (2005) 1582-1592, http://dx.doi.org/10.1016/j. compscitech.2005.01.008.

[21] D.R. Bauer, Interpreting weathering acceleration factors for automotive coatings using exposure models, Polym. Degrad. Stabil. 69 (2000) 307-316, http://dx.doi. org/10.1016/S0141-3910(00)00074-4.

[22] Y. Peng, R. Liu, J. Cao, Y. Chen, Effects of UV weathering on surface properties of polypropylene composites reinforced with wood flour, lignin, and cellulose, Appl. Surf. Sci. 317 (2014) 385-392, http://dx.doi.org/10.1016/j.apsusc.2014.08.140.

[23] D. Rosu, R. Bodîrləu, C.A. Teacə, L. Rosu, C.D. Varganici, Epoxy and succinic 
anhydride functionalized soybean oil for wood protection against UV light action, J. Clean. Prod. 112 (2016) 1175-1183, http://dx.doi.org/10.1016/j.jclepro.2015.07. 092.

[24] R. Gadioli, J.A. Morais, W.R. Waldman, M.-A. De Paoli, The role of lignin in polypropylene composites with semi-bleached cellulose fibers: mechanical properties and its activity as antioxidant, Polym. Degrad. Stabil. 108 (2014) 23-34, http:// dx.doi.org/10.1016/j.polymdegradstab.2014.06.005.

[25] U. Schulz, V. Wachtendorf, T. Klimmasch, P. Alers, The influence of weathering on scratches and on scratch and mar resistance of automotive coatings, Prog. Org. Coating 42 (2001) 38-48, http://dx.doi.org/10.1016/S0300-9440(01)00148-5.

[26] N. Tahmassebi, S. Moradian, S.M. Mirabedini, Evaluation of the weathering performance of basecoat/clearcoat automotive paint systems by electrochemical properties measurements, Prog. Org. Coating 54 (2005) 384-389, http://dx.doi. org/10.1016/j.porgcoat.2005.08.004.

[27] P. Šimon, M. Fratričová, P. Schwarzer, H.W. Wilde, Evaluation of the residual stability of polyurethane automotive coatings by DSC: equivalence of Xenotest and desert weathering tests and the synergism of stabilizers, J. Therm. Anal. Calorim. 84 (2006) 679-692, http://dx.doi.org/10.1007/s10973-005-7549-z.

[28] S. Overton, J. Manura, Identification of Volatile Organic Compounds in a New Automobile, (1999).

[29] B. Xu, Y. Wu, Y. Gong, S. Wu, X. Wu, S. Zhu, T. Liu, Investigation of volatile organic compounds exposure inside vehicle cabins in China, Atmos. Pollut. Res. 7 (2015) 215-220, http://dx.doi.org/10.1016/j.apr.2015.09.005.

[30] M.J. Fedoruk, B.D. Kerger, Measurement of volatile organic compounds inside automobiles, J. Expo. Anal. Environ. Epidemiol. 13 (2003) 31-41, http://dx.doi.org/ 10.1038/sj.jea.7500250.

[31] J.S. Han, J.S. Rowell, Chemical composition of fibers, in: R.M. Rowell, R.A. Young, J.K. Rowell (Eds.), Pap. Compos. From Agro-based Resour, CRC/Lewis Publishers, 1996, pp. 84-134.

[32] J. Acera Fernández, N. Le Moigne, A.S. Caro-Bretelle, R. El Hage, A. Le Duc, M. Lozachmeur, P. Bono, A. Bergeret, Role of flax cell wall components on the microstructure and transverse mechanical behaviour of flax fabrics reinforced epoxy biocomposites, Ind. Crop. Prod. 85 (2016) 93-108, http://dx.doi.org/10. 1016/j.indcrop.2016.02.047.

[33] ISO 877-1, Plastics - Methods of Exposure to Solar Radiation - Part 1: General Guidance, (2011)

[34] ISO 877-2, Plastics - Methods of Exposure to Solar Radiation - Part 2: Direct Weathering and Exposure behind Window Glass, (2011).

[35] Pau-Uzein meteorological station, Real-time Weather Reports, (2016) http://www. infoclimat.fr/observations-meteo/temps-reel/pau-uzein/07610.html , Accessed date: 16 June 2017.

[36] ISO 178:2010, Plastics - Determination of Flexural Properties, (2010).

[37] R. Alexander-Katz, R.G. Barrera, Surface correlation effects on gloss, J. Polym. Sci. 36 (1997) 1321-1334.

[38] ISO 2813: Coatings: Determination of Gloss Value at $20^{\circ}, 60^{\circ}$ and $85^{\circ},(2014)$, pp. $1-31$.

[39] L.H. Sperling, Introduction to Physical Polymer Science, 4th Ed, John Wiley \& Sons, 2006, http://dx.doi.org/10.1002/0471757128.ch9.
[40] C. Rouillon, P.O. Bussiere, E. Desnoux, S. Collin, C. Vial, S. Therias, J.L. Gardette, Is carbonyl index a quantitative probe to monitor polypropylene photodegradation? Polym. Degrad. Stabil. 128 (2016) 200-208, http://dx.doi.org/10.1016/j. polymdegradstab.2015.12.011.

[41] Joanne Will, Does my windshield protect me from the sun? Global Med. (2013), https://www.theglobeandmail.com/globe-drive/culture/commuting/does-mywindshield-protect-me-from-the-sun/article12495123 , Accessed date: 16 August 2017.

[42] L. Běhálek, M. Maršálková, P. Lenfeld, J. Habr, J. Bobek, M. Seidl, Study of crystallization of polylactic acid composites and nanocomposites with natural Fibres by DSC method, Nanocon Conf. (2013) 1-6.

[43] L. Soccalingame, A. Bourmaud, D. Perrin, J.-C. Bénézet, A. Bergeret, Reprocessing of wood flour reinforced polypropylene composites: impact of particle size and coupling agent on composite and particle properties, Polym. Degrad. Stabil. 113 (2015) 72-85, http://dx.doi.org/10.1016/j.polymdegradstab.2015.01.020.

[44] N.S. Egute, P.L. Forster, F.D. Parra, D.M. Fermino, S. Santana, A.B. Lugão, Mechanical and thermal properties of polypropylene composites with curaua fibre, Int. Nucl. Atl. Conf. 2009 978-85-99141-03-8.

[45] M. John, S. Thomas, Biofibres and biocomposites, Carbohydr. Polym. 71 (2008) 343-364, http://dx.doi.org/10.1016/j.carbpol.2007.05.040.

[46] B. Fayolle, E. Richaud, J. Verdu, F. Farcas, Embrittlement of polypropylene fibre during thermal oxidation, J. Mater. Sci. 43 (2007) 1026-1032, http://dx.doi.org/ 10.1007/s10853-007-2242-1.

[47] L. Wei, A.G. McDonald, C. Freitag, J.J. Morrell, Effects of wood fiber esterification on properties, weatherability and biodurability of wood plastic composites, Polym. Degrad. Stabil. 98 (2013) 1348-1361, http://dx.doi.org/10.1016/j. polymdegradstab.2013.03.027.

[48] J.S. Félix, C. Domeño, C. Nerín, Characterization of wood plastic composites made from landfill-derived plastic and sawdust: volatile compounds and olfactometric analysis, Waste Manag. 33 (2013) 645-655, http://dx.doi.org/10.1016/j.wasman. 2012.11.005.

[49] J. Li, H.-C. Hu, X.-S. Chai, Rapid method for determination of carbonyl groups in lignin compounds by headspace gas chromatography, J. Chromatogr. A 1404 (2015) 39-43, http://dx.doi.org/10.1016/j.chroma.2015.05.055.

[50] K. Srinivas, K.K. Pandey, Photodegradation of thermally modified wood, J. Photochem. Photobiol. B Biol. 117 (2012) 140-145, http://dx.doi.org/10.1016/j. jphotobiol.2012.09.013.

[51] H. Du, W. Wang, Q. Wang, S. Sui, Y. Song, Effects of ultraviolet absorbers on the ultraviolet degradation of rice-hull/high-density polyethylene composites, J. Appl. Polym. Sci. 126 (2012) 906-915, http://dx.doi.org/10.1002/app.36558.

[52] A.J. Vinha, A.G. Carvalho, M. Teixeira de Souza, C. Marangon Jardim, A. de Cassia Oliveira Carneiro, J. Luiz Colodette, Effect of extractives on wood color of heat treated Pinus radiata and Eucalyptus pellita, Maderas Cienc. Tecnol. 17 (2015) 857-864, http://dx.doi.org/10.4067/S0718-221X2015005000074.

[53] J.S. Fabiyi, D. McIlroy, A.G. McDonald, Wood modification effects on weathering of HDPE-based wood plastic composites, J. Polym. Environ. 17 (2009) 34-48, http:// dx.doi.org/10.1007/s10924-009-0118-y. 